\title{
Nucleic acid-mediated autoinflammation and autoimmunity-type I interferonopathies
}

\author{
Min Ae Lee-Kirsch ${ }^{1}$ - Claudia Günther ${ }^{2}$ - Axel Roers ${ }^{3}$
}

Published online: 15 September 2016

(C) Springer-Verlag Berlin Heidelberg 2016

Type I interferons (IFN), IFN- $\alpha$, and IFN- $\beta$ play a central role in the immune defense against viral infections. While IFN- $\alpha$ is mainly secreted by plasmacytoid dendritic cells, IFN- $\beta$ can be produced by almost every cell. Type I IFNs are induced by engagement of pattern recognition receptors of the innate immune system that recognize danger signals originating from pathogen-derived molecular patterns. Detection of viral infection by the host organism is primarily achieved through recognition of viral nucleic acids. Within the cytosol, dsDNA, and ssDNA are sensed by the nucleotidyl transferase cyclic GMP-AMP synthase (cGAS), which catalyzes the synthesis of the second messenger cyclic GMP-AMP (cGAMP) leading to activation of the adapter molecule STING (Fig. 1) [1, 2]. Cytosolic dsRNA is recognized by the RNA helicases retinoic acidinducible gene 1 (RIG-I) and melanoma differentiationassociated protein 5 (MDA5), which recruit the mitochondrial antiviral signaling (MAVS) adapter protein [3]. Both STING and MAVS activate interferon stimulatory factor 3 (IRF3) through phosphorylation by TANK-binding kinase 1 (TBK1) resulting in the transcriptional activation of the

Min Ae Lee-Kirsch

minae.lee-kirsch@uniklinikum-dresden.de

1 Department of Pediatrics, Medizinische Fakultät Carl Gustav Carus, Technische Universität Dresden, Fetscherstr. 74, 01307 Dresden, Germany

2 Department of Dermatology, Medizinische Fakultät Carl Gustav Carus, Technische Universität Dresden, Fetscherstr. 74, 01307 Dresden, Germany

3 Institute for Immunology, Medizinische Fakultät Carl Gustav Carus, Technische Universität Dresden, Fetscherstr. 74,

01307 Dresden, Germany interferon genes and of numerous interferon-stimulated genes (ISGs). Collectively, these transcriptional responses induce an antiviral state and enable cells to restrict viral spread and to eliminate infected cells through modulation of innate and adaptive immune responses (Fig. 1). Binding of type I IFNs to the interferon- $\alpha$ receptor (IFNAR), a cell surface receptor composed of two subunits, activates the Janus kinase (JAK) — signal transducer and activator of transcription (STAT) pathway-leading to transcription of ISGs [4]. Importantly, a complex interplay of host, pathogen, and environmental factors modulates the innate and adaptive immune responses to type I IFN signaling and determines whether pathogens are cleared effectively or chronic infection or autoimmune disease ensues. Consequently, inappropriate activation of the type I IFN system can be detrimental to the host by promoting inflammatory responses and a break of immune tolerance leading to autoimmunity.

While the pattern recognition receptors, cGAS, RIG-I, and MDA5, alert the host to viral infection by sensing viral nucleic acids, their capacity to differentiate between nonself and self DNA or RNA is limited. As a result, a type I IFN response can in principle also be initiated by endogenous nucleic acids, which means that the host organism must be equipped with efficient means to prevent inappropriate type I IFN activation by self nucleic acids. Indeed, type I IFN activation induced by immune recognition of self nucleic acids is central to the pathogenesis systemic lupus erythematosus (SLE), a chronic relapsing autoimmune disease that can virtually affect any organ system [5].

The elucidation of the molecular pathology of rare Mendelian disorders associated with inappropriate activation of the type I IFN axis has provided novel insight into cellintrinsic disease mechanisms underlying autoinflammation and autoimmunity. Collectively, these disorders are referred to as type I interferonopathies, a term coined by Yanick 


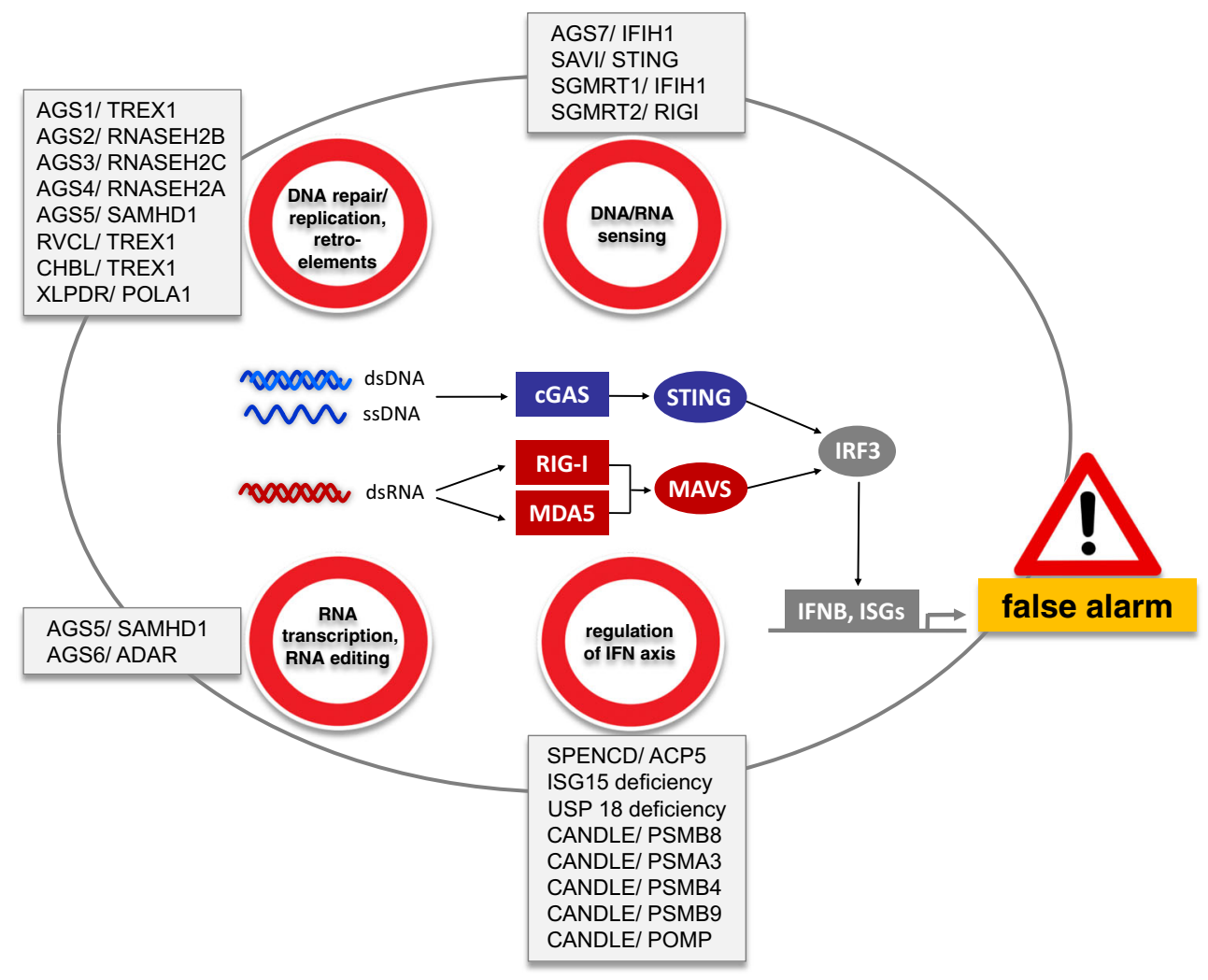

Fig. 1 Disease pathways leading to nucleic acid-induced type I IFN activation. Deficiency in the DNase TREX1 results in cytosolic accumulation of ssDNA derived from aberrant DNA replication intermediates, DNA repair metabolites, or reverse transcription of retroelements. Defective removal of ribonucleotides from genomic DNA due to RNase H2 (RNASEH2A, RNASEH2B, RNASEH2C) deficiency or imbalanced deoxynucleotide (dNTP) pools due to SAMHD1 deficiency, respectively, causes genome instability leading to enhanced formation of DNA repair metabolites. Similarly, a lack of DNA polymerase $\alpha$ (POLA1) is thought to result in the build-up of RNA:DNA hybrids. The DNA by-products of these pathways act as danger signals that activate cGAS-dependent type I IFN signaling. The RNase activity of SAMHD1 may also prevent accumulation of yet unknown immunostimulatory RNA species. Editing of endogenous dsRNA by the deaminase ADAR prevents MDA5-mediated sensing of dsRNA as nonself. Gain-of-function mutations in the dsRNA sensors RIG-I and

Crow in 2011 [6]. Type I interferonopathies comprise a growing number of genetically determined disorders that are caused by a dysfunction of the innate immune system. While the clinical spectrum of the type I interferonopathies is highly variable and broad, neurological and cutaneous manifestations represent the most salient findings [7, 8]. In addition, signs of immunodeficiency with recurrent infections can be observed in certain disease entities [9-11]. Although the implicated genes exert diverse biological functions, the associated disease pathways converge to a common route which is inappropriate overproduction of type I IFN (Table 1) [8]. Thus, chronic type I IFN activation results from defects in the metabolism or the immune recognition of intracellular nucleic acids or in altered pathways that regulate the type I IFN axis (Fig. 1). Deficiency in the nucleases TREX1 or
MDA5 (encoded by the IFIH1 gene) or in the cGAMP-binding adaptor molecule STING leads to inadequately or constitutively increased type I IFN signaling. Loss of tartrate-resistant acid phosphatase (encoded by the $A C P 5$ gene) or of interferon-stimulated protein 15 (ISG15) or ubiquitinspecific protease 18 (USP18) alters pathways that negatively regulate the type I interferon axis. Deficiency of components of the immunoproteasome (PSMB8, PSMA3, PSMB4, PSMB9, POMP) causes chronic type I IFN activation by yet unknown mechanisms that may involve antigen presentation. AGS Aicardi-Goutières syndrome, RVCL retinal vasculopathy with cerebral leukodystrophy, $C H B L$ familial chilblain lupus, $X L P D R \mathrm{X}$-linked reticulate pigmentary disorder, $S A V I$ STING-associated vasculopathy, infantile-onset, SGMRT SingletonMerton syndrome, SPENCD spondyloenchrondrodysplasia, CANDLE chronic atypical neutrophilic dermatosis with lipodystrophy and elevated temperature

RNase $\mathrm{H} 2$, a lack of the triphosphohydrolase activity of SAMHD1 or loss of the DNA polymerase $\alpha$ results in abnormal accumulation of nucleic acids emanating from DNA repair/replication or the life cycle of retroelements causing a spectrum of phenotypes including Aicardi-Goutières syndrome (AGS), retinal vasculopathy with cerebral leukodystrophy (RVCL), familial chilblain lupus (CHBL), or X-linked reticulate pigmentary disorder (XLPDR) [11-17]. Similarly, a lack of the RNA-specific deaminase ADAR or loss of the RNase activity of SAMHD1 alters the chemical properties of RNA or causes accumulation of RNA species which triggers type I IFN activation [18, 19]. Enhanced sensitivity or ligandindependent activation of the nucleic acid sensors RIG-I or MDA5 (encoded by the IFHI gene) or of the signal adaptor STING underlies Singleton-Merton syndrome (SGMRT1, 
Table 1 Genes implicated in type I interferonopathies

\begin{tabular}{|c|c|c|}
\hline Gene & Protein function & Phenotypes \\
\hline TREXI & $\begin{array}{l}\text { Three prime repair exonuclease } \\
\text { Cytosolic DNase }\end{array}$ & $\begin{array}{l}\text { Aicardi-Goutières syndrome } \\
\text { Retinal vasculopathy with } \\
\text { cerebral leukodystrophy } \\
\text { Familial chilblain lupus } \\
\text { Systemic lupus erythematosus }\end{array}$ \\
\hline $\begin{array}{l}\text { RNASEH } 2 A \\
\text { RNASEH } 2 B \\
\text { RNASEH } 2 C\end{array}$ & $\begin{array}{l}\text { Ribonuclease } \mathrm{H} 2 \text {, subunits A, B, C } \\
\text { Ribonucleotide excision repair }\end{array}$ & $\begin{array}{l}\text { Aicardi-Goutières syndrome } \\
\text { Systemic lupus erythematosus }\end{array}$ \\
\hline SAMHD1 & $\begin{array}{l}\text { SAM domain and HD domain-containing } \\
\text { protein } 1 \\
\text { dNTP triphosphohydrolase, RNase }\end{array}$ & $\begin{array}{l}\text { Aicardi-Goutières syndrome } \\
\text { Familial chilblain lupus } \\
\text { Systemic lupus erythematosus }\end{array}$ \\
\hline$A D A R 1$ & $\begin{array}{l}\text { Adenosine deaminase, RNA-specific } \\
\text { Deamination of adenosine to inosine in dsRNA }\end{array}$ & Aicardi-Goutières syndrome \\
\hline$I F I H 1$ & $\begin{array}{l}\text { IFN-induced helicase } \mathrm{C} \text { domain-containing protein } 1 \\
\text { Pattern recognition receptor for dsRNA }\end{array}$ & $\begin{array}{l}\text { Aicardi-Goutières syndrome } \\
\text { Singleton-Merten syndrome }\end{array}$ \\
\hline STING & $\begin{array}{l}\text { Stimulator of interferon genes } \\
\text { IFN- } \beta \text { induction in response to cytosolic DNA }\end{array}$ & $\begin{array}{l}\text { STING-associated vasculopathy, } \\
\text { infantile-onset Familial chilblain lupus }\end{array}$ \\
\hline$A C P 5$ & $\begin{array}{l}\text { Tartrate-resistant acid phosphatase, type } 5 \\
\text { Dephosphorylation of osteopontin }\end{array}$ & Spondyloenchrondrodysplasia \\
\hline$R I G I$ & $\begin{array}{l}\text { Retinoic acid-inducible gene } 1 \\
\text { Pattern recognition receptor for dsRNA }\end{array}$ & Singleton-Merten syndrome \\
\hline$I S G 15$ & $\begin{array}{l}\text { Interferon-stimulated gene } 15 \\
\text { Ubiquitin-like protein, modifies proteins } \\
\text { by ISGylation }\end{array}$ & ISG15 deficiency \\
\hline USP18 & $\begin{array}{l}\text { Ubiquitin-specific protease } 18 \\
\text { de-ISGylation }\end{array}$ & USP18 deficiency \\
\hline PSMB 8 & $\begin{array}{l}\text { Proteasome subunit } \beta 5 \mathrm{i} \\
\text { Antigen processing in immunoproteasome }\end{array}$ & $\begin{array}{l}\text { CANDLE syndrome } \\
\text { (chronic atypical neutrophilic }\end{array}$ \\
\hline PSMB4 & $\begin{array}{l}\text { Proteasome subunit } \beta 7 \\
\text { Antigen processing in immunoproteasome }\end{array}$ & $\begin{array}{l}\text { dermatosis with lipodystrophy } \\
\text { and elevated temperature) }\end{array}$ \\
\hline PSMA3 & $\begin{array}{l}\text { Proteasome subunit } \alpha 7 \\
\text { Antigen processing in immunoproteasome }\end{array}$ & \\
\hline PSMB9 & $\begin{array}{l}\text { Proteasome subunit } \beta 1 \mathrm{i} \\
\text { Antigen processing in immunoproteasome }\end{array}$ & \\
\hline$P O M P$ & $\begin{array}{l}\text { Proteasome maturation protein } \\
\text { Formation of immunoproteasome }\end{array}$ & \\
\hline POLA1 & $\begin{array}{l}\text { DNA polymerase } \alpha \\
\text { Synthesis of RNA:DNA primers during } \\
\text { DNA replication }\end{array}$ & $\begin{array}{l}\mathrm{X} \text {-linked reticulate pigmentary } \\
\text { disorder }\end{array}$ \\
\hline
\end{tabular}

SGMRT2), AGS and STING-associated vasculopathy (SAVI), respectively [20-23]. Finally, dysregulation of pathways that modulate type I IFN signaling can cause ISG15 or USP18 deficiency, spondyloenchondrodysplasia, or CANDLE syndrome [10, 24-26].

Taken together, the discovery of cytosolic sensing pathways along with the genetic dissection of the type I interferonopathies has revealed novel mechanisms that protect the organism against inappropriate immune activation caused by self nucleic acids, while maintaining a prompt and efficient immune response to foreign nucleic acids. These scientific advances not only provide a set of molecules and pathways such as IFN- $\alpha / \beta$, the IFNAR receptor, or the JAK/STAT pathway that could already potentially be targeted for specific therapeutic intervention, but will also foster the development of novel compounds targeting other components of the type I IFN axis such as cGAS, TBK1, and STING.

The review by Andrea Ablasser and Muhammed Gulen focuses on the role of cGAS in DNA sensing mechanisms and its role in disease processes leading to autoimmunity and cancer [27]. Carl Walkley and Jacki Heraud-Farlow review the role of the deaminase ADAR in the discrimination of 
foreign and self RNA molecules by MDA5 through chemical modification of dsRNA by deamination [28]. Lars Rönnblom and Maija-Leena Eloranta give an overview on the multifaceted roles of type I IFN in the pathogenesis of SLE, which unlike the monogenic type I interferonopathies is a complex multifactorial disorder [29]. Last but not the least, Raphaela Goldbach-Mansky and her colleagues review the genetic and clinical findings of the type I interferonopathies SAVI and CANDLE in contrast to AGS and monogenic forms of SLE and provide insight into the underlying disease mechanisms [30].

\section{References}

1. Cai X, Chiu Y-H, Chen ZJ (2014) The cGAS-cGAMP-STING pathway of cytosolic DNA sensing and signaling. Mol Cell 54: 289-296

2. Herzner AM, Hagmann CA, Goldeck M, Wolter S, Kubler K, Wittmann S, Gramberg T, Andreeva L, Hopfner KP, Mertens C, et al. (2015) Sequence-specific activation of the DNA sensor cGAS by Y-form DNA structures as found in primary HIV-1 cDNA. Nat Immunol 16:1025-1033

3. Atianand MK, Fitzgerald KA (2013) Molecular basis of DNA recognition in the immune system. J Immunol 190:1911-1918

4. Ivashkiv LB, Donlin LT (2014) Regulation of type I interferon responses. Nat Rev Immunol 14:36-49

5. Marshak-Rothstein A (2006) Toll-like receptors in systemic autoimmune disease. Nat Rev Immunol 6:823-835

6. Crow YJ (2011) Type I interferonopathies: a novel set of inborn errors of immunity. Ann N Y Acad Sci 1238:91-98

7. Crow YJ, Manel N (2015) Aicardi-Goutières syndrome and the type I interferonopathies. Nat Rev Immunol 15:429-440

8. Lee-Kirsch MA, Wolf C, Kretschmer S, Roers A (2015) Type I interferonopathies-an expanding disease spectrum of immunodysregulation. Semin Immunopathol 37:349-357

9. Briggs TA, Rice GI, Daly S, Urquhart J, Gornall H, Bader-Meunier B, Baskar K, Baskar S, Baudouin V, Beresford MW, et al. (2011) Tartrate-resistant acid phosphatase deficiency causes a bone dysplasia with autoimmunity and a type I interferon expression signature. Nat Genet 43:127-131

10. Zhang X, Bogunovic D, Payelle-Brogard B, Francois-Newton V, Speer SD, Yuan C, Volpi S, Li Z, Sanal O, Mansouri D, et al. (2015) Human intracellular ISG15 prevents interferon-alpha/beta overamplification and auto-inflammation. Nature 517:89-93

11. Starokadomskyy P, Gemelli T, Rios JJ, Xing C, Wang RC, Li H, Pokatayev V, Dozmorov I, Khan S, Miyata N, et al. (2016) DNA polymerase- $\alpha$ regulates the activation of type I interferons through cytosolic RNA:DNA synthesis. Nat Immunol 17:495-504

12. Yang YG, Lindahl T, Barnes DE (2007) Trex1 exonuclease degrades ssDNA to prevent chronic checkpoint activation and autoimmune disease. Cell 131:873-886

13. Stetson DB, Ko JS, Heidmann T, Medzhitov R (2008) Trex1 prevents cell-intrinsic initiation of autoimmunity. Cell 134:587-598

14. Reijns MA, Rabe B, Rigby RE, Mill P, Astell KR, Lettice LA, Boyle S, Leitch A, Keighren M, Kilanowski F, et al. (2012) Enzymatic removal of ribonucleotides from DNA is essential for mammalian genome integrity and development. Cell 149: $1008-1022$
15. Hiller B, Achleitner M, Glage S, Naumann R, Behrendt R, Roers A (2012) Mammalian RNase H2 removes ribonucleotides from DNA to maintain genome integrity. J Exp Med 209:1419-1426

16. Gunther C, Kind B, Reijns MA, Berndt N, Martinez-Bueno M, Wolf C, Tungler V, Chara O, Lee YA, Hubner N, et al. (2015) Defective removal of ribonucleotides from DNA promotes systemic autoimmunity. J Clin Invest 125:413-424

17. Kretschmer S, Wolf C, Konig N, Staroske W, Guck J, Hausler M, Luksch H, Nguyen LA, Kim B, Alexopoulou D, et al. (2015) SAMHD1 prevents autoimmunity by maintaining genome stability. Ann Rheum Dis 74(3):e17. doi:10.1136/annrheumdis-2013204845

18. Liddicoat BJ, Piskol R, Chalk AM, Ramaswami G, Higuchi M, Hartner JC, Li JB, Seeburg PH, Walkley CR (2015) RNA editing by ADAR1 prevents MDA5 sensing of endogenous dsRNA as nonself. Science 349:1115-1120

19. Ryoo J, Choi J, Oh C, Kim S, Seo M, Kim SY, Seo D, Kim J, White TE, Brandariz-Nunez A, et al. (2014) The ribonuclease activity of SAMHD1 is required for HIV-1 restriction. Nat Med 20:936-941

20. Rice GI, Del Toro DY, Jenkinson EM, Forte GM, Anderson BH, Ariaudo G, Bader-Meunier B, Baildam EM, Battini R, Beresford MW, et al. (2014) Gain-of-function mutations in IFIH1 cause a spectrum of human disease phenotypes associated with upregulated type I interferon signaling. Nat Genet 46:503-509

21. Rutsch F, MacDougall M, Lu C, Buers I, Mamaeva O, Nitschke Y, Rice GI, Erlandsen H, Kehl HG, Thiele H, et al. (2015) A specific IFIH1 gain-of-function mutation causes Singleton-Merten syndrome. Am J Hum Genet 96:275-282

22. Jang MA, Kim EK, Now H, Nguyen NT, Kim WJ, Yoo JY, Lee J, Jeong YM, Kim CH, Kim OH, et al. (2015) Mutations in DDX58, which encodes RIG-I, cause atypical Singleton-Merten syndrome. Am J Hum Genet 96:266-274

23. Liu Y, Jesus AA, Marrero B, Yang D, Ramsey SE, Montealegre Sanchez GA, Tenbrock K, Wittkowski H, Jones OY, Kuehn HS, et al. (2014) Activated STING in a vascular and pulmonary syndrome. N Engl J Med 371:507-518

24. Meuwissen MEC, Schot R, Buta S, Oudesluijs G, Tinschert S, Speer SD, Li Z, van Unen L, Heijsman D, Goldmann T, et al. (2016) Human USP18 deficiency underlies type 1 interferonopathy leading to severe pseudo-TORCH syndrome. J Exp Med. doi:10.1084/jem.20151529

25. Liu Y, Ramot Y, Torrelo A, Paller AS, Si N, Babay S, Kim PW, Sheikh A, Lee CC, Chen Y, et al. (2012) Mutations in proteasome subunit beta type 8 cause chronic atypical neutrophilic dermatosis with lipodystrophy and elevated temperature with evidence of genetic and phenotypic heterogeneity. Arthritis Rheum 64:895-907

26. Brehm A, Liu Y, Sheikh A, Marrero B, Omoyinmi E, Zhou Q, Montealegre G, Biancotto A, Reinhardt A, Almeida de Jesus A, et al. (2015) Additive loss-of-function proteasome subunit mutations in CANDLE/PRAAS patients promote type I IFN production. J Clin Invest 125:4196-4211

27. Ablasser A, Gulen MF (2016) The role of cGAS in innate immunity and beyond. J Mol Med Berl. doi:10.1007/s00109-016-1423-2

28. Heraud-Farlow JE, Walkley CR (2016) The role of RNA editing by ADAR1 in prevention of innate immune sensing of self-RNA. J Mol Med Berl. doi:10.1007/s00109-016-1416-1

29. Eloranta ML, Rönnblom L (2016) Cause and consequences of the activated type I interferon system in SLE. J Mol Med Berl. doi:10.1007/s00109-016-1421-4

30. Kim H, Montealegre Sanchez GA, Goldbach-Mansky R (2016) Clinical insights from Mendelian autoinflammatory interferonopathies: CANDLE, SAVI versus AGS, monogenic lupus. J Mol Med Berl. doi:10.1007/s00109-016-1465-5 